\title{
The Relationships Between State Community College Governance Centralization and Local Appropriations
}

\author{
Lindsey Hammond \\ University of Georgia/United States \\ Sean Baser \\ University of Georgia/United States \\ Alexander Cassell \\ Pennsylvania State University/ United States
}

\begin{abstract}
This two-way, fixed effects analysis examines the relationship between local appropriations and community college state governance structures while examining governance's moderating impact on state-level factors. We find that any type of statelevel organization for community colleges does not impact local appropriations, and that in states with no formal coordinating authority, local appropriations are likely to be higher. Further, the absence of a state-level board, even one that includes fouryear, primary, or secondary education, moderates the relationship between unemployment and appropriations. This relationship suggests that in states without a state-level board for community colleges, local governments invest in and leverage their community colleges in times of economic decline. Based on our findings, resisting centralization efforts might be to the benefit of community colleges in terms of finances and autonomy; however, this does not consider the impacts varying degrees of centralization might have on stakeholders outside of the local appropriations process.
\end{abstract}

Keywords: Community Colleges, Governance, Governing Boards, Educational Finance, Local Appropriations, Educational Policy 
Community colleges are local institutions with a historic commitment to serving the needs of their surrounding area (Cohen, Brawer, \& Kisker, 2013). Policymakers at the state (Sponsler, Pingel, \& Anderson, 2015) and federal (AACC \& ACCT, 2019) levels, however, are increasingly interested in leveraging community colleges to meet workforce and economic development goals. In 2019, 258 bills were introduced in 49 states related to workforce development and postsecondary education (Keily, 2019, November). The increased attention to community colleges by state policymakers aligns with the growing trend of state centralization for community college governance (Fletcher \& Friedel, 2017). That is to say, as community colleges become more important to policymakers, states seem to be exerting more control over the sector. In many cases, the goals of local communities and states are likely in alignment, however, it is likely conflict exists between some local and state priorities. Debates around state community college governance reform underscore the complicated relationship between local and state control as well as the tension between institutional autonomy and public accountability. As community colleges become increasingly central to policymaker attempts to address the nation's need for a more credentialed workforce, understanding the complex relationships moderating state policy and community colleges will be useful for researchers, policymakers, and practitioners.

The effect of governance on various higher education public policy outcomes is well explored as it relates to four-year institutions (Hearn \& McLendon, 2012), but lacking in terms of community colleges (Fletcher \& Friedel, 2017). Existing research documents that in the presence or absence of different governance structures, the impact of several state-level factors, especially those related to political factors, commonly modeled in higher education policy research is attenuated or amplified (Tandberg, 2013). Further, some of this research has examined the relationship between governance structures and state appropriations (Nicholson-Crotty \& Meier, 2003; Tandberg, 2010a). These authors generally argue that states with strong, centralized governance structures would have greater capacity and influence in state government as compared to states with less centralized governing structures. As a result of this capacity and influence, centralized state governance structures should receive more state appropriations. However, when examining the relationship between state governance structures and local appropriations, it may be that more centralized governance structures are associated with less local fiscal support.

The relationship between statewide community college governance structures and appropriations also has important implications for the sector's ability to serve its myriad stakeholders. This is particularly important as it relates to the community college sector because community colleges already receive the least funding per student and serve the majority of students most in need of additional support (Bailey \& Morest, 2006). Taken together, the lack of research on community college governance and tensions between local and state control creates a rich opportunity to better understand the dynamic relationships between governance and finance. We focus our inquiry on local appropriations to center questions of local versus state autonomy for community colleges. The following research questions guide this study: 


\section{Higher Education Politics \& Economics}

1) What, if any, relationship exists between state-level community college governance and local appropriations?

2) What, if any, governance arrangements moderate the effect of state-level characteristics on the flow of local appropriations to community colleges?

\section{LITERATURE REVIEW}

\section{State-level Postsecondary Governance Structures}

Statewide coordination of higher education has evolved since its broad emergence in the 1950s and 1960s (Hearn \& Griswold, 1994; McGuinness, 2016). States established centralized governing boards in response to the "historical surge in college enrollments, increasing sprawl in state systems of higher education, trenchant interinstitutional rivalries, and the growing regulatory capability of state governments" (McLendon, 2003, pp. 479-480). The trend toward more centralized postsecondary governance structures signaled a shift in authority from institutions to state governments. Over the past few decades, however, statewide centralization efforts have retrenched in some states as the counter trend of decentralization emerged as a popular proposal for state policymakers (McLendon, 2003; Mclendon \& Hearn, 2009). Even so, decentralization is not a universal trend with many states continuing to consider and adopt governance reforms that bolster state control.

A promising line of research on statewide governance structures has emerged in higher education, both descriptive and empirical (Hearn \& McLendon, 2012). A key contribution from the descriptive vein of research is the development of classification systems to describe the variety of governance arrangements based on the authority, role, and functions of agencies. State governance arrangements have generally been placed into three general groups (from most to least centralized): consolidated governing boards, coordinating boards, and higher education service agencies ("planning agencies") (Glenny, 1985; McGuinness, 2016). There is significant variation within these buckets because the authority and influence of each state's agency is largely a consequence of the political, socio-economic, and organizational conditions of the state. A limitation of these classifications is that scholars generally focus their efforts on four-year governance structures.

Empirical research examining relationships between statewide governance structures and a variety of policy outcomes (e.g., academics, finance, teacher education, and accountability) has blossomed over the past few decades (Hearn \& McLendon, 2012; Tandberg \& Griffith, 2013). Within this growing body of literature, a number of scholars have examined whether state governance structures are a determinant of state spending on higher education (Lowry, 2001; McLendon, Hearn, \& Mokher, 2009; Nicholson-Crotty \& Meier, 2003; Tandberg, 2010a, 2010b; Tandberg \& Ness, 2011). In two recent studies using fixed-effects models, centralized statewide governing boards were associated with a decline in state appropriations (Tandberg, 2010a) and capital expenditures (Tandberg \& Ness, 2011). Tandberg (2010a) suggests that this may be because "in states with less centralized structures, the institutions may have greater access to elected officials and therefore engage more 
in the political process" (p. 763). Other studies did not find centralized governance structures to be a significant predictor of state spending in higher education (McLendon et al., 2009). Additionally, perhaps through their role as boundaryspanning organizations, research indicates that statewide governing agencies moderate several state-level political factors thought to affect appropriations (Tandberg, 2013). While research in this area has evolved greatly, there are contradictory results as to the nature of the relationships between governance, state political factors, and finance for higher education (Hearn \& McLendon, 2012). Authors agree, however, that more nuanced research on governance is needed to better understand these complex policy relationships. Few studies have examined whether state governance structures influence state or local policy outcomes for community colleges.

\section{State-level Community College Governance}

State-level community college governance structures generally evolved toward increased state control and centralization. Early community colleges were established as upward extensions of public secondary schools with courses taught by high school teachers. Local tax funds provided most of the operating revenue for community colleges before 1950 (Cohen et al., 2013); this reflected the strong alignment with the community, a value that has persisted throughout the history of community colleges. Although most authority remained local, state authority over community college governance generally resided with state boards of education before 1960 (Dougherty, 1994). Between 1963 and 2015, the number of states using a separate state board for community colleges increased from 6 to 19 (Fletcher \& Friedel, 2017). Increased state investment in the community college sector was often proffered by policymakers to community college leaders as a persuasive factor for centralization. This noticeable shift toward growing state control through formal authority and funding suggests that community college governance structures are more centralized, though the impacts of centralization on decision-making authority remain unclear.

The existing literature for statewide community college governance is primarily descriptive. Several scholars developed state-level typologies of community college governance structures (Fletcher \& Friedel, 2017; Garrett, 1992; Katsinas, 1996; Tollefson, 2009; Tollefson \& Fountain, 1992; Tollefson, Garrett, \& Ingram, 1999), which offer meaningful contributions to the field by providing much-needed analysis on how community colleges are organized. Many of these typologies have borrowed from more comprehensive typologies and descriptions of governance structures (Glenny, 1985; McGuinness, 2016).They illuminate the differences between two- and four-year postsecondary governance structures and "serv[ed] as an analytical resource underpinning future empirical investigations" (Hearn \& McLendon, 2012, p. 64). While scholars generally concluded that community college governance structures trend toward centralization, the degree to which a system is centralized varies. The variation aligns with the widely held notion that each state is a unique setting with various political, social, organizational, and economic conditions that influence the governance structures and policy outcomes. 


\section{Higher Education Politics \& Economics}

Over the past few decades, researchers conducted several studies that complement the descriptive work on community college governance. Some scholars have examined how the growing influence of state governments in community college affairs affected the local orientation and autonomy of community colleges (Fonte, 1993; Ingram \& Tollefson, 1996). Although most literature detailed the erosion of local autonomy as states allocated more funding to community colleges and adopted centralized governance for community colleges, Ingram and Tollefson (1996) found evidence to the contrary and argued that personnel, academic, and administrative decisions are primarily local decisions.

Several studies explored the relationship between state governance and funding at the community colleges (Fletcher \& Friedel, 2018; Garrett, 1993). For example, in one of the first empirical studies on the topic, Garrett (1993) found that state governance structures were more likely to be centralized when community colleges received a higher percentage of their revenue from state funding, whereas community colleges receiving a higher percentage of funding from local sources tended to be less centralized. In a more recent study, Fletcher and Friedel (2018) used a cross-sectional correlational analysis to examine the relationships between state-level community college governance systems, state funding distribution formulae, and revenue resource funds in 2014. They found that states without a centralized community college coordinating or governing board received the highest amount of revenue from tuition and fees. Relevant to our study, Fletcher and Friedel (2018) found that in states where community colleges are governed by the same coordinating board as K-12, but separate from universities, received the least amount of revenue from local sources per FTE, while "states whose [community colleges] fell under the jurisdiction of a university system board were highest, on average, for revenues from local support per FTE" (Fletcher \& Friedel, 2018, p. 13).

Taken together, these studies suggest that state-level community college governance structures influence local funding and decision making. While the research around and attention to community college governance is growing, there is a dearth in published scholarship examining the relationships between varying levels of centralization and localization in community college governance arrangements and centralization's impact on funding and practice. This gap in the literature is particularly acute for research using quantitative analysis to explore the role of governance structures on community colleges over time.

\section{CONCEPTUAL FRAMEWORK}

Significant variation exists within and between states in regard to how community colleges are organized, governed, and funded (Friedel, Killacky, Miller, \& Katsinas, 2014). This variation is largely a consequence of the organizational, political, and socio-economic conditions within individual states. Overall, the ever-growing body of literature examining the effect of these conditions on higher education policy have concluded that "a constellation of state demographic (e.g., enrollment growth), economic (changes in tax revenues and employment conditions), political (the ideological proclivities of citizenries and party control of government institutions) and governance conditions drive state policy change and reform in postsecondary 
education" (Hearn \& McLendon, 2012, p. 66). As such, we draw upon an ecology of state higher-education policymaking along with our summary of previous research on state governance of two- and four-year institutions to understand how community colleges fit within the broader state context. Using prior research on state higher education policymaking, Hearn and Ness (2017) suggested that shifts in state policy are the result of "four distinct sets of forces: (1) the socio-economic contexts of states; (2) the organizational and policy contexts of states; (3) the politico-institutional contexts of states; and, 4) the external contexts of states" (p. 24). In the rest of this section, we provide a brief description of each context and a cursory review of how the variables used in this study fit within their respective context. A review of the external context has been omitted because our research questions are focused on statelevel characteristics; however, external factors, such as federal government support or intermediary organization activity, certainly influence state policy for community colleges.

\section{Socioeconomic Context}

The socioeconomic context of a state is crucial to understand policy decisions in higher education. For this paper, we include the following economic and demographic measures that have been found to be significant predictors of postsecondary policy decisions: population, income inequality, and unemployment. Here, population is viewed as an effort measure wherein states with "larger populations may have a larger tax base (taxable citizens, products, commerce, and industries) and therefore be able to direct greater resources toward higher education" (Tandberg \& Griffith, 2013, p. 636). Additionally, income inequality in a state can affect appropriations to higher education. In this line of thinking, as the concentration of wealth increases in a state, appropriations to higher education decline because more affluent voters prefer reduced taxes and government subsidies (Doyle, 2007). Income inequality may exacerbate issues for community colleges because of the sector's dependence on appropriations as a revenue source. Finally, unemployment is a key determinant of higher education finance policy. Researchers postulate that states with high unemployment rates may have weak economies, and therefore will have less ability to fund higher education (Tandberg, 2010b; Toutkoushian \& Hollis, 1998). Moreover, the unemployment rate has unique and salient implications for community colleges because of their mission to serve local communities. For example, Hillman and Orians (2013) found that higher rates of unemployment were associated with increases in enrollment at community colleges, which provides evidence to the role community colleges play in educating unemployed and displaced workers to spur economic recovery efforts (Dougherty \& Bakia, 1999).

\section{Organizational \& Policy Context}

It is well established that wide variation exists among the states in the organization, governance, and finance of higher education. The three major facets of the organizational and policy context include the organizational ecology, agency analytic capacity, and policy postures. The organizational ecology is characterized by 


\section{Higher Education Politics \& Economics}

factors such as the number and distribution of institutions by control and level and the number and distribution of students by institution type. A higher share of community college students in a state might lead policymakers to invest additional resources as there is demand in the sector. The organizational and policy context is important to understanding a state's need for public higher education, and specifically community colleges. The diversity of institutions in a state and how states fund higher education have salient implications for community colleges.

\section{Politico-institutional Context}

The political conditions and institutional arrangements of a state represent another important context that influences state policy for higher education. The politico-institutional context is composed of eight dimensions, including higher education governance arrangements, the nature of the appointment characteristics for the state higher-education agency's executive officer, political ideology, gubernatorial characteristics, legislative characteristics, partisanship conditions, interest-group climates, and in-state intermediary organizations (for a detailed review, see: McLendon \& Hearn, 2007; Tandberg \& Griffith, 2013). The political conditions of a state can help explain why voters and policymakers make certain decisions. For example, some scholars have found evidence that postsecondary appropriations are higher in liberal states (Archibald \& Feldman, 2006; Tandberg, 2010a).

\section{METHOD}

\section{Data}

We create a unique state-level panel dataset spanning the years 2000-2015 with 800 observations for analysis. The dependent variable and other control measures include an array of state-level policy ecology factors and were gathered from publicly available online resources, such as the Integrated Postsecondary Education Data System (IPEDS), the U.S. Census, and KlarnerPolitics. See Table 1 in the supplemental materials section for detailed definitions of the variables used in our study.

\section{Dependent Variable}

The dependent variable is the dollar amount of total local appropriations received by all community colleges per FTE in a state each year. The variable was created by taking the sum of all local appropriations reported by institutions to IPEDS in the state for that year and dividing that by the sum of all FTE reported by institutions to IPEDS in the state for that year. FTE is a "single value providing a meaningful combination of full-time and part-time students" (IPEDS, 2017, p. 4). In the absence of a dataset standardizing local influence in community college governance, we rely on this to serve as a proxy for local influence. 


\section{Primary Independent Variables of Interest}

This is a set of six dichotomous variables describing the structure of state community college governance. We constructed a dichotomous variable for each governance category in alignment with the taxonomy outlined in Katsinas (1996) and further expanded upon by Fletcher and Friedel (2017). To begin, we used Tollefson, Garrett, and Ingram's (1999) book of community college governance summaries to categorize each state (Table 2 in supplemental materials).

Next, we compared the 1999 categorization with Fletcher and Friedel's (2017) categorizations (Table 3 in supplemental materials). In instances in which the governance structure changed between 1999 and 2015, we utilized webpages from the Education Commission of the States (ECS) and state websites to identify the year in which the change occurred and the type of governance change. To further ensure validity, we vetted the independent variable against internet searches for the name of each state's governing board and change and/or history. This schema does not include measures to compare the relative power of an organizing body (i.e. coordinating versus governing board powers).

Previous research categorizes community college governance structures into the following mutually exclusive categories: (1) states with a board that is separate from both K-12 and four-year governance; (2) states with a board that has oversight for both community colleges and the K-12 institutions; (3) states with a board that has responsibility for community colleges and four-year institutions; (4) states with a board responsible for all P-20 institutions; (5) states that assign responsibility for community college governance to a four-year system board; and (6) states that do not have any formal coordinating or governing board for community colleges. In the instance of each variable, 1 indicates the presence of one of the six typology categories and 0 indicates the absence of that organizational arrangement.

\section{Policy Ecology Independent Variables}

Recognizing the policy context in which community colleges and their governance structures operate, we included a wide variety of state-level factors as controls and, through our use of interaction terms, as an integral piece of our analysis (Hearn \& Ness, 2017).

\section{Analysis}

We approached analysis in two phases to identify the optimum estimation strategy and then estimated three sets of models for each of the six types of community college governance. All models were estimated with additional robustness checks to properly account for the panel structure of our data and the complex relationships among our variables. In the first phase, we estimated a naïve linear regression. We next employed a two-way, fixed effects regression with year and state serving as fixed effects to better account for the time and place dependent nature of our data (Allison, 2009). Next, we tested a random effects regression with year and state serving as fixed effects. We then used the Hausman test to compare the 


\section{Higher Education Politics \& Economics}

results from the fixed and random effects models, the two typical approaches to estimation on panel data. Based on the test, we concluded that the two-way, fixed effects regression was the superior model (Chmelarova, 2007). Conceptually, we favor this approach because it accounts for unobserved confounders (Imai \& Kim, 2016). Finally, we clustered all standard errors to account for potential autocorrelation or heteroskedasticity (Angrist \& Pischke, 2009).

After identifying the two-way, fixed effects models as the optimum estimation strategy (Equation 1), we estimated two additional sets of models. The second set of models (Equation 2) feature interaction terms to test the dependence of variables on one another. We were primarily interested in testing the dependence of state-level policy variables on governance structure because prior research on four-year governance suggests that governance plays a conditioning role on various policy factors in relation to state appropriations for higher education (Tandberg, 2013).

To test this relationship, we multiplied the policy ecology independent variables by the dichotomous governance variable. The models are depicted formally below.

(1) LocalAppropsFTE $\mathrm{it}_{\mathrm{i}}=\alpha+\beta_{1} \mathrm{CCg}_{\mathrm{it}}+\beta_{2} \mathrm{PEC}_{\mathrm{it}}+\mu_{\mathrm{i}}+\delta_{\mathrm{i}}+\eta_{\mathrm{t}}+\varepsilon_{\mathrm{it}}$

(2) LocalAppropsFTE $\mathrm{it}=\alpha+\beta_{1} \mathrm{CCg}_{\mathrm{it}}+\beta_{2} \mathrm{PEC}_{\mathrm{it}}+\beta_{3} \mathrm{CCg}_{\mathrm{it}}{ }^{*} \mathrm{PEC}_{\mathrm{it}}+\mu_{\mathrm{i}}+\delta_{\mathrm{i}}+\eta_{\mathrm{t}}+\varepsilon_{\mathrm{it}}$

In the formal depiction, LocalAppropsFTE $E_{\text {it }}$ serves as the dependent variable and represents the dollar amount of local appropriations per FTE for an individual state $\mathrm{i}$ in year t. $\beta_{1}$ represents regression coefficients corresponding to one of the two categorical variables created to represent state governance arrangements for community colleges, $\beta_{2}$ represents the regression coefficients corresponding to control variables from the policy ecology framework, and $\beta_{3}$ (included in Equation 2) represents the regression coefficients corresponding to interaction terms between the governance variable and policy ecology controls. Finally, $\mu_{\mathrm{i}}, \delta_{\mathrm{i}}, \eta$, and $\varepsilon_{\mathrm{it}}$ represent the constant for the states, state effects term, time effects term, and the error term for state $i$ at time t, respectively.

We conducted an F-test to compare the results between the first (Equation 1) and second set of models (Equation 2) and determined that adding the interaction terms significantly improved the models. Our third set of models included a split sample with two regressions: one that included only observations by year and state with a consolidated governing board and one without any consolidated governance. This set of models enables us to determine the relationship between independent and dependent variables for states with those governance arrangements.

We conducted sensitivity checks to ensure the robustness of our results. Because of known flaws in IPEDS reporting for community colleges nested in systems (Jaquette \& Parra, 2016), we conducted a sensitivity analysis by excluding all grouped institutions. Finally, we ran a Variance Inflation Factor test to ensure multicollinearity was not biasing our estimates (Willett \& Murnane, 2010). In the instances in which the VIF was greater than the standard cutoff of 10 , we reran our models without those variables to ensure that statistical significance was not falsely reached by including those variables. Results remained robust to sensitivity checks. See supplemental materials for details. 


\section{FINDINGS}

Summary statistics in the form of means, standard deviations, minimums, and maximums are presented in Table 4 for the full sample $(N=800)$. Regarding our dependent variable of interest, on average, local appropriations to community colleges were about $\$ 460$ per full-time equivalent (FTE) student between 2000 and 2015. On average, states appropriated $\$ 4,881.26$ per FTE student, though significant variation existed within and between the states. For example, over the 15-year period, Colorado appropriated the least amount per FTE $(\$ 1,180.43)$ on average, whereas Alaska appropriated the most per FTE $(\$ 13,887.08)$. Overall, the share of students in community colleges was about $35 \%$. Florida and California are two of the states with the highest proportion of students at community colleges. On the other hand, Alaska and Delaware are among the states with the smallest proportion of students attending community colleges. Democrats did not have unified control of the state legislature in more than half of our observations (38\%). The average state population in our sample was about $6,000,000$ and the unemployment rate was $5.86 \%$.

Table 4. Descriptive Statistics

Variable Name $\quad \underline{M} \quad \underline{\text { SD }} \quad \underline{M i n} \quad \underline{M a x}$

\section{Dependent Variables}

Local Appropriations for

Community Colleges per FTE

Organizational \& Policy Context

CC Governance Variable

Coefficient

State Appropriations per FTE

Share of Students in CCs

\section{Politico-Institutional Context}

State Citizen Ideology

Legislative Control

(Democrat)

Governor Power

\section{Socioeconomic Context}

State Population

Income Inequality (Gini

Coefficient)

Unemployment Rate

Note: Sample size $=800$
$\$ 461.54 \quad \$ 608.76 \quad \$ 0.00 \quad \$ 2,833.38$

$\begin{array}{llll}0.39 & 0.49 & 0.00 & 1.00\end{array}$

$\$ 4,881.27 \quad \$ 2,231.92 \quad \$ 104.14 \quad \$ 16,713.54$

$\begin{array}{llll}0.35 & 0.13 & 0.01 & 0.61\end{array}$

$\begin{array}{cccc}51.98 & 16.03 & 8.45 & 95.97 \\ 0.38 & 0.49 & 0.00 & 1.00 \\ 0.82 & 0.14 & 0.50 & 1.00\end{array}$

$\begin{array}{cccc}6,030,947 & 6,652,599 & 494,300 & 38,993,940 \\ 43.58 & 2.99 & 34.03 & 51.38 \\ 5.86 & 2.00 & 2.10 & 14.00\end{array}$




\section{Higher Education Politics \& Economics}

The results of our analysis are presented in Table 5. Our first research question concerns whether there was a relationship between state-level community college governance and local appropriations. We found that the only community college governance organizational type associated with appropriations is the variable indicating that the state had no formal organizational system for community colleges. For the sake of comparison, we show results for the models for the organizational type indicating the presence of a centralized community college board distinct from K-12 and other postsecondary boards, which was not associated with local appropriations (Model 1). The lack of any community college organizational system was associated with a \$256 increase in local appropriations (Model 2) and, when interaction terms were included, the magnitude was much larger at \$2032 (Model 4).

State appropriations for higher education, unemployment rate, and population were all significant interaction terms as well (Model 4). Stated differently, in states where a community college governing board does not exist, rising unemployment is linked to increases in local appropriations. In the presence of any type of governance structure, unemployment is not a significant predictor of local appropriations. However, in the absence of state governance, a $1 \%$ increase in unemployment is associated with a \$46/FTE increase in local appropriations. In the absence of a governance structure for community colleges, the modest, though positive relationship between state appropriations and local appropriations is amplified. Increases in state appropriations are associated with an additional $\$ 0.06 /$ FTE increase in local appropriations. Although the coefficient for state population was statistically significant, it is practically insignificant.

Our final set of models (Models 5 and 6) provide an additional window into our second research question about the moderating influence of community college governance. In the final set, we disaggregate our data based on the presence or absence of a centralized community college governing board. We find that in the sample of states without centralized governance, sector enrollment distribution and unemployment are significant predictors, while state appropriations is an insignificant predictor of local appropriations. This model (6), however, has a small sample size and generally supports the findings from our interaction model (4). Readers may consider this to be a robustness check to illustrate the relationships between the independent variables and dependent variable for this specific type of governance arrangement. 



\section{DISCUSSION}

Overall, our study yields two main findings. First, any type of centralized governance structure for the community college sector is not associated with a change in local appropriations. This is consistent, regardless of the type of centralized structure. That is to say, the relationship between local appropriations and community college governance housed in any of the five governance arrangements we categorized ((1) states with a board that is separate from both K12 and four-year governance; (2) states with a board that has oversight for both community colleges and the K-12 institutions; (3) states with a board that has responsibility for community colleges and four-year institutions; (4) states with a board responsible for all P-20 institutions; and (5) states that assign responsibility for community college governance to a four-year system board) are equally unimpactful. Second, the lack of any centralized governance for community colleges is associated with an increase in local appropriations. We recognize, however, that this finding is based on three states (Arizona, Pennsylvania, and South Dakota). This finding is consistent with previous findings on centralization and appropriations (Garrett, 1993; Fletcher \& Friedel, 2018) as well as conclusions from the literature on the utilization of community colleges by their local communities in times of economic hardship (Hillman \& Orians, 2013) we do explore this finding further and provide practical implications for researchers, practitioners, and policymakers. In the two sections that follow, we elaborate on the implications for our two main findings and then finish with a list of questions designed to spark further policy-relevant research on the role of community college governance.

Our finding that state centralization is not associated with a decrease in local appropriations for community colleges is likely good news for the sector, especially within the context of the strong trend toward increasing state centralization over the past decades. The steady local appropriations indicate that in the presence of a statewide organizational structure for community colleges, local communities are not disinvesting. Practitioners and policymakers in the three states without centralized governance should weigh the potential effects of centralization against the possibility of steady, but not increasing, local appropriations. Some of the benefits of state boards might be that they are better equipped to lobby policymakers, provide institutions with technical assistance for policy implementation, and aid in how state funding is distributed across the system due to their role as boundary-spanning organizations (Tandberg, 2013) In contrast, a state system might constrain local autonomy. Based on our second main finding, this restriction of autonomy might be problematic as it relates to a community college's ability to respond nimbly to economic downturns. From a researcher standpoint, we are curious to understand how local politics impact local appropriations, especially within the midst of external factors, like economic downturns. Further, we are interested in exploring the ways that local appropriations influence decision making. 
Our finding suggesting that the absence of a state-wide organizing structure for community colleges alters the flow of local appropriations during times of rising unemployment is also relevant for policymakers and practitioners. The finding supports the notion that local governments depend on nearby community colleges to assist in upskilling displaced workers in times of economic decline (Hillman \& Orians, 2013). Policymakers and practitioners in states with a statewide governance structure for community colleges maintain their level appropriations, but do not increase appropriations. Because rising levels of unemployment are also associated with rising levels of community college enrollment, community colleges might need to expand their capacity to meet the increased demand. Community colleges might need to expand facilities or available programs to best meet the needs of their communities. Expansion of existing services, not to mention the addition of programs, however, likely necessitates additional spending. Not increasing resources in times of increased demand may hinder the community college's ability to facilitate economic recovery. States with centralized community college governance may be missing an opportunity to respond in a targeted fashion to local conditions. Researchers should examine the response in Arizona, Pennsylvania, and South Dakota post-recession to evaluate whether the increased investment in community colleges was an effective economic stabilization strategy.

Relatedly, our finding that no formal organizational system for community colleges leads to a positive relationship between state and local appropriations warrants further exploration. This mirrors literature that state governments are willing to invest money in higher education in times of prosperity (Delaney \& Doyle, 2011; Hovey, 1999). Our findings indicate that in states without centralized community college governance, local governments are more likely to appropriate to community colleges, and that in times of economic decline, they will invest even more. Although local appropriations do not decrease in in times of economic decline for states with centralized community governance, future research should consider whether the same is true for state appropriations to the sector. Again, we suggest that state policymakers consider the increased load placed on community colleges in times of economic decline and encourage states to consider using community colleges to bounce back from economic decline. Practitioners should continue monitoring current economic conditions and be prepared for an influx of students, especially students from post-traditional backgrounds, in times of rising unemployment.

Far more research on the relationship between local autonomy and state centralization is needed to more rigorously evaluate the effects of community college governance. The inclusion of local-level policy ecology variables or qualitative analysis of the role of municipal politics may reveal why any type of state-level organization for community colleges does not impact local appropriations. Methodological advances in spatial analytic techniques may also prove fruitful in pursuing this line of inquiry. Further, developing a measure of governance centralization for community colleges, similar to what exists in the fouryear literature, may help to nuance and explore the relationship between the levels of strength of governance and local appropriations. It is possible that in states with strong governing boards, local appropriations decline while in states with weak 


\section{Higher Education Politics \& Economics}

coordinating boards, local appropriations remain steady. With a similar local orientation as community colleges, scholars may also want to consider literature on K-12 policy (Kirst, 2010). These scholars have long tussled with how state centralization and community factors impede institutional autonomy and affect local spending. Because research on the long-term effects of community college governance is relatively nascent, especially in the contemporary context, there are many opportunities to expand upon our study.

Below are a few future research questions scholars may want to consider when examining how governance affects higher education policy and economics:

- Does the degree of centralization (i.e. coordinating versus governing boards) impact the conditioning effects of community college governance?

- Does investing in the community college sector truly mitigate economic crises? If so, how?

- Do state level political factors affect community colleges and four-year institutions differently? If so, how and why?

- How do state level political factors interact with municipal political factors? Do these factors impact two- and four-year institutions differently? If so, how and why?

- Why are local appropriations higher in states without centralized community college governance? Are local governments more willing to invest because they are aware of the community needs and the way that community colleges respond? Does more lobbying occur on a local level?

- Do local appropriations come with spending conditions for campuses or do they come in the form of general appropriations? In other words, do local appropriations restrict campus autonomy?

- Are local appropriations more or less stable than state appropriations? How might this inform budgeting?

- How do existing resource disparities among urban, suburban, and rural locales impact local appropriations? Does this affect the ability of community colleges to serve their local communities?

For states without any type of state-level community college governance, resisting centralization may be wise, especially in terms of preserving the ability of community colleges to respond nimbly in challenging economic times. This strategy, however, does not take into consideration the other parts of centralization that might be beneficial to institutions. This caveat is especially important given our findings that having a state-level board to manage community colleges does not decrease local appropriations. The results of our study strongly suggest that community college governance warrants further research, especially as it relates to the complex relationships between state and local control.

\section{REFERENCES}

Allison, P. D. (2009). Fixed effects regression models (Vol. 160). Thousand Oaks, CA: SAGE Publications. 
American Association of Community College, \& Association of Community College Trustees. (2019). Joint legislative agenda for the 116th congress:

Advancing American community colleges. Retrieved from: https://www.aacc.nche.edu/wp-content/uploads/2019/02/LegAgenda18.pdf

Angrist, J. D., \& Pischke, J.-S. (2009). Mostly harmless econometrics: An empiricist's companion. Princeton, NJ: Princeton University Press.

Archibald, R. B., \& Feldman, D. H. (2006). State higher education spending and the tax revolt. The Journal of Higher Education, 77(4), 618-644.

Bailey, T. W., \& Morest, V. S. (2006). Defending the community college equity agenda. Baltimore, MD: Johns Hopkins University Press.

Chmelarova, V. (2007). The hausman test, and some alternatives, withheteroskedastic data. (Doctoral dissertation), Retrieved from https://digitalcommons.lsu.edu/cgi/viewcontent.cgi?article=1935\&context=grad school_dissertations

Cohen, A. M., Brawer, F. B., \& Kisker, C. B. (2013). The American community college. San Fransisco, CA: Jossey-Bass.

Delaney, J. A., \& Doyle, W. R. (2011). State spending on higher education: Testing the balance wheel over time. Journal of Education Finance, 36(4), 343-368.

Dougherty, K. J. (1994). The contradictory college : The conflicting origins, impacts, and futures of the community college. Albany, NY: State University of New York Press.

Doyle, W. R. (2007). The political economy of redistribution through higher education subsidies. In J. C. Smart (Ed.), Higher education: Handbook of theory and research (pp. 335-409). Dordrecht: Springer Netherlands.

Fletcher, J. A., \& Friedel, J. N. (2017). Typology of state-level community college governance structures. Community College Journal of Research and Practice, 41(4-5), 311-322. doi:10.1080/10668926.2016.1251355

Fletcher, J. A., \& Friedel, J. N. (2018). Interrelationships between funding and state community college governance systems. Journal of Applied Research in the Community College, 25(1), 1-15.

Fonte, R. W. (1993). The impact of state financing and regulation on the local orientation of community colleges. Community College Review, 21(1), 4-14. doi:10.1177/009155219302100102

Friedel, J. N., Killacky, J., Miller, E., \& Katsinas, S. G. (2014). Fifty state systems of community colleges: Mission, governance, funding, and accountability (Fourth ed.). Johnson City, TN: Overmountain Press.

Garrett, R. L. (1992). Degree of centralization of governance of state community college systems in the United States, 1990. Community College Review, 20(1), 7-13. doi: $10.1177 / 009155219202000102$

Garrett, R. L. (1993). A profile of state community college system characteristics and their relationship to degrees of centralization. Community College Review, 20(5), 6-15. doi:10.1177/009155219302000502

Glenny, L. A. (1985). State coordination of higher education: The modern concept. Retrieved from: https://files.eric.ed.gov/fulltext/ED270070.pdf

Hearn, J. C., \& Griswold, C. P. (1994). State-level centralization and policy innovation in US postsecondary education. Educational Evaluation and Policy 


\section{Higher Education Politics \& Economics}

Analysis, 16(2), 161-190. doi:10.3102/01623737016002161

Hearn, J. C., \& McLendon, M. K. (2012). Governance research: From adolescence toward maturity. In M. Bastedo (Ed.), The organization of higher education: Managing colleges for a new era (pp. 45-85). Baltimore, MD: The John Hopkins University Press.

Hearn, J. C., \& Ness, E. C. (2017). The ecology of state-higher education policymaking in the US. In D. Palfreyman, T. Tapper, \& S. Thomas (Eds.), Towards the private funding of higher education: Ideological and political struggles (pp. 19-47). London, UK: Routledge.

Hillman, N. W., \& Orians, E. L. (2013). Community colleges and labor market conditions: How does enrollment demand change relative to local unemployment rates? Research in Higher Education, 54(7), 765-780. doi:10.1007/s11162-013-9294-7

Hovey, H. (1999). State spending for higher education in the next decade: The battle to sustain current support. Retrieved from: https://files.eric.ed.gov/fulltext/ED439633.pdf

Ingram, W. G., \& Tollefson, T. A. (1996). Local autonomy is alive and well: The results of a national study on locations of effective decision-making authority in state community college systems. Community College Journal of Research and Practice, 20(2), 133-150. doi:10.1080/1066892960200203

Jaquette, O., \& Parra, E. (2016). The problem with the delta cost project database. Research in Higher Education, 57(5), 630-651. doi:10.1007/s11162-015-9399-2

Katsinas, S. G. (1996). A typology of community college governance structures [unpublished manuscript].

Keily, T. (2019, November). Postsecondary workforce development policies. Retrieved from: https://www.ecs.org/wp-content/uploads/PostsecondaryWorkforce-Development-Policies.pdf

Kirst, M. W. (2010). The political and policy dynamics of K-12 education reform from 1965 to 2010: Implications for changing postsecondary education.

Retrieved from:

https://cepa.stanford.edu/sites/default/files/Evolution\%20of\%20K12_9_2_10.pdf

Lowry, R. C. (2001). The effects of state political interests and campus outputs on public university revenues. Economics of Education Review, 20(2), 105-119. doi:https://doi.org/10.1016/S0272-7757(99)00069-2

McGuinness, A. C. (2016). History of state coordination and governance and alternatives for the future. Retrieved from: http://www.ecs.org/wpcontent/uploads/051616-State-Policy-Leadership-for-the-Future-KL-final2.pdf

McLendon, M. K. (2003). Setting the governmental agenda for state decentralization of higher education. The Journal of Higher Education, 74, 479515. doi: $10.1353 /$ jhe. 2003.0038

McLendon, M. K., \& Hearn, J. C. (2007). Incorporating political indicators into comparative state study of higher education policy. In K. M. Shaw \& D. E. Heller (Eds.), State postsecondary education research: New methods to inform policy and practice (pp. 11-36). Sterling, VA: Stylus.

Mclendon, M. K., \& Hearn, J. C. (2009). Viewing recent US governance reform 
whole: "Decentralization" in a distinctive context. In J. Huisman (Ed.), International perspectives on the governance of higher education: Alternative frameworks for coordination (pp. 161-181). New York, NY: Routledge.

McLendon, M. K., Hearn, J. C., \& Mokher, C. G. (2009). Partisans, professionals, and power: The role of political factors in state higher education funding. The Journal of Higher Education, 80(6), 686-713. doi:10.1080/00221546.2009.11779040

Nicholson-Crotty, J., \& Meier, K. J. (2003). Politics, structure, and public policy: The case of higher education. Educational Policy, 17(1), 80-97. doi: $10.1177 / 0895904802239287$

Sponsler, B. A., Pingel, S., \& Anderson, L. (2015). Policy trends impacting community colleges: An ecs perspective. Community College Journal of Research and Practice, 39(10), 891-895. doi:10.1080/10668926.2015.1033786

Tandberg, D. A. (2010a). Interest groups and governmental institutions: The politics of state funding of public higher education. Education Policy, 24(5), 735-778. doi: $10.1177 / 0895904809339163$

Tandberg, D. A. (2010b). Politics, interest groups and state funding of public higher education. Research in Higher Education, 51(5), 416-450. doi:10.1007/s11162010-9164-5

Tandberg, D. A. (2013). The conditioning role of state higher education governance structures. The Journal of Higher Education, 84(4), 506-543. doi:10.1080/00221546.2013.11777300

Tandberg, D. A., \& Griffith, C. (2013). State support of higher education: Data, measures, findings, and directions for future research. In M. B. Paulsen (Ed.), Higher education: Handbook of theory and research: Volume 28 (pp. 613-685). Dordrecht: Springer Netherlands.

Tandberg, D. A., \& Ness, E. C. (2011). State capital expenditures for higher e education: "Where the real politics happens". Journal of Education Finance, 36(4), 394-423.

Tollefson, T. A. (2009). Community college governance, funding, and accountability: A century of issues and trends. Community College Journal of Research and Practice, 33(3-4), 386-402. doi:10.1080/10668920802580481

Tollefson, T. A., \& Fountain, B. E. (1992). Forty-nine state systems. Washington, D.C.: American Association of Community Colleges.

Tollefson, T. A., Garrett, R. L., \& Ingram, W. G. (1999). Fifty state systems of community colleges: Mission, governance, funding and accountaility. Johnson City, TN: Overmountain Press.

Toutkoushian, R. K., \& Hollis, P. (1998). Using panel data to examine legislative demand for higher education. Education Economics, 6(2), 141-157.

Willett, J. B., \& Murnane, R. (2010). Methods matter: Improving causal inference in educational and social science research. New York, NY: Oxford University Press. 
LINDSEY HAMMOND is a doctoral student in the Institute of Higher Education at University of Georgia. Her major research interests are centered at the intersections of public policy, community colleges, workforce development, and social theory. Email: lindsey.hammond25@uga.edu

SEAN BASER is a doctoral student in the Institute of Higher Education at University of Georgia. His major research interests lie in the area of the politics and policy of education, concentrating on higher education governance, interest groups, and community colleges. Email: sean.baser25@uga.edu

ALEXANDER CASSELL is a doctoral student in the Department of Education Policy Studies at The Pennsylvania State University. His research interests focus on higher education policy, governance, finance, and economics. Email: acc5851@psu.edu 